\title{
Hubungan Antara Perilaku Konsumtif Pada Produk X Dengan Citra Diri Remaja Putri
}

\author{
R. A. Adinah Suryati Ningsih, Yudho Bawono \\ dhobano@yahoo.co.id
}
Program Studi Psikologi, Fakultas Ilmu Sosial dan Ilmu Budaya, Universitas Trunojoyo, Madura, Indonesia

\begin{abstract}
Penelitian ini dilakukan dengan tujuan untuk mengetahui hubungan antara perilaku konsumtif pada produk X dengan citra diri remaja putri. Penelitian ini menggunakan metode penelitian pendekatan kuantitatif korelasional dengan menyebarkan skala perilaku konsumtif yang terdiri dari 28 butir dan skala citra diri yang terdiri dari 34 butir kepada 125 konsumen (member) pada produk X. Analisis data dilakukan dengan teknik correlation bivariate Pearson dengan bantuan program SPSS 21.00 for Windows. Dari hasil analisis data diperoleh nilai koefisien korelasi sebesar 0,481 dengan nilai signifikansi sebesar 0,000 dari signifikansi $0,05 \quad(5 \%)$ yang menyatakan bahwa penelitian ini memiliki korelasi keeratan sedang dan memiliki hubungan yang positif. Hal ini menunjukkan bahwa ada hubungan yang signifikan antara perilaku konsumtif pada produk X dengan citra diri remaja putri. Sehingga dapat dikatakan bahwa peningkatan citra diri akan diikuti dengan perilaku konsumtif, yaitu semakin tinggi citra diri maka akan semakin tinggi perilaku konsumtif.
\end{abstract}

Kata kunci: perilaku konsumtif, citra diri, remaja putri

Sejak dulu hingga kini, tidak dapat dipungkiri bahwa penampilan merupakan salah satu hal yang seringkali mendapat perhatian, khususnya bagi seorang wanita. Penampilan serta kecantikan merupakan modal utama bagi mereka. Terlebih dengan adanya statement di masyarakat bahwa seorang wanita harus selalu tampil cantik dan menarik, maka para wanita berupaya untuk mewujudkan hal tersebut. Kecantikan bagi seorang wanita merupakan suatu kebutuhan. Oleh karena itu, mereka mempunyai keinginan untuk memperbaiki kekurangannya (Kompas, 2011).

Demikian pula dengan remaja putri, mereka juga memiliki keinginan untuk tampil cantik dan menarik. Bahkan agar menjadi cantik dan menarik, para remaja putri biasanya menggunakan atribut, baik busana dan aksesoris yang bernilai mahal atau bermerek, seperti sepatu, tas, pakaian, dan sebagainya yang dapat menunjang penampilan mereka. Menurut Reynold (dalam Rosandi, 2004), remaja putri banyak yang membelanjakan uangnya untuk kebutuhannya dalam berpenampilan pada pemakaian produk, seperti pakaian, kosmetik, assesoris, dan sepatu.

Masa remaja yang merupakan periode transisi kehidupan manusia dari anak-anak menuju dewasa, di dalamnya terdapat proses pencarian jati diri. Hal ini yang menyebabkan seorang remaja mudah untuk ikut atau terimbas hal-hal yang tengah terjadi di sekitarnya (Santrock, 
2003). Remaja di sekitar juga terpengaruh oleh trend dan mode yang terjadi, sehingga menjadikan remaja selalu ingin mengikuti arus perkembangan dan gaya hidup yang terjadi saat itu juga.

Para remaja cenderung selalu ingin memiliki barang-barang tersebut dan berlebihan dalam membeli atau mengonsumsi. Sikap atau perilaku remaja yang mengkonsumsi barang secara berlebihan dan tidak wajar inilah yang disebut perilaku konsumtif. Perilaku konsumtif yang banyak terjadi pada remaja putri pada umumnya hanya sebatas keinginan terhadap barang-barang tersebut dan belum tentu sesuai dengan kebutuhan. Selain itu, remaja putri yang lebih bersifat konsumtif terhadap pakaian dengan merek terkenal. Pakaian dengan merek terkenal dianggap jauh lebih berkualitas dan lebih mampu meningkatkan rasa percaya diri, terutama saat mereka mengenakannya (Susianto, 1993).

Hal ini dapat dilihat jika saat ini perubahan pola hidup remaja dalam melakukan pembelian produk menjadi sangat menonjol. Kenyataan ini dilihat dari banyaknya produk yang dikenalkan kepada remaja dalam berbagai bentuk dan kemasan yang menarik. Produk yang ditawarkan dengan kemasan menarik akan memudahkan terjerat dalam perilaku yang kurang efisien, antara lain dengan penjualan langsung (direct selling) atau dengan penjualan tidak langsung (catalogue) maupun promosi dengan jalan pemasangan iklan lewat media (Sabirin, 2005). Salah satu produk yang sistem penjualannya demikian adalah produk X.

Pemicunya adalah mereka terus melakukan pembelian terhadap produk $\mathrm{X}$. Produk ini didesain untuk semua kalangan sesuai dengan trend dan kebutuhan khususnya remaja putri. Akibat dari suatu kebutuhan yang sudah mulai tidak bersifat wajar dalam membeli produk $\mathrm{X}$ tersebut, membuat remaja putri memanfaatkan kondisi bagaimana cara mereka mendapatkan keinginannya. Keinginan yang dialami oleh remaja putri jika membeli produk $\mathrm{X}$ secara terus-menerus akan menimbulkan perilaku konsumtif, karena menimbulkan keinginan yang berlebihan dalam pembelian yang terusmenerus berganti model dengan merek produk yang sama pada produk X. Hal ini sebagaimana diungkapkan oleh salah seorang remaja putri (AA) yang peneliti temukan sebagai berikut:

"Akan muncul rasa bangga pada diri saya dan menjadi orang yang disorot sebagai seorang yang cantik, indah, modis, dan menarik ketika diri saya menggunakan produk berkelas, dan trend di saat ini, saya membeli produk ini kurang lebih tiga dalam sekali pesan, meskipun harus bisa hemat jajan untuk bisa membeli produk ini, itu pun saya mengeluh dengan masalah keuangan saya" (wawancara pada tanggal 4 Oktober 2014).

Dalam membeli produk $\mathrm{X}$ tersebut, remaja putri yang masih tergantung dengan orang tua dalam menghidupi kebutuhannya, akan melakukan bermacam tindakan yang tidak seharusnya dilakukan. Keinginan yang dialami remaja putri dalam membeli produk $\mathrm{X}$ secara terusmenerus akan menimbulkan perilaku konsumtif, karena menimbulkan keinginan yang berlebihan dalam pembelian produk $\mathrm{X}$ yang terus-menerus berganti model.

Sejak dahulu hingga saat ini tidak dapat dipungkiri penampilan merupakan salah satu hal yang seringkali mendapat perhatian khusus bagi seorang wanita. Penampilan serta kecantikan merupakan modal utama bagi mereka. Seorang wanita 
harus selalu tampil cantik dan menarik. Rasa cantik bagi seorang wanita dapat dikatakan merupakan sebuah kebutuhan, sehingga dalam perkembangannya, wanita selalu mempunyai keinginan dan selalu ada kekurangan pada dirinya. Dengan demikian, wanita akan memperbaiki kekurangan yang dimiliki dan perilaku konsumtif dapat mendukung citra diri seseorang.

Berdasarkan uraian di atas, peneliti ingin mengetahui hubungan kedua variabel tersebut. Adapun hipotesis yang diajukan di dalam penelitian ini yaitu ada hubungan antara perilaku konsumtif pada produk $\mathrm{X}$ dengan citra diri remaja putri.

\section{Metode}

\section{Desain}

Penelitian ini menggunakan metode penelitian pendekatan kuantitatif korelasional, untuk mengetahui hubungan antara perilaku konsumtif pada produk $\mathrm{X}$ dengan citra diri remaja putri.

Lokasi penelitian dilakukan di tempat salah satu member pada produk X cabang di Kabupaten Pamekasan pada tanggal 25 Juni 2015.

\section{Partisipan}

Sampel penelitian ini berjumlah 125 orang dengan teknik pengambilan sampel yaitu purposive sampling yaitu teknik pengambilan sampel dengan pertimbangan tertentu, yaitu: a) remaja putri yang berusia 18 sampai dengan 21 tahun, b) berpenampilan rapi, sopan, dan menggunakan aksesoris, c) konsumen (member) pada produk X, dan d) minimal pendidikan SMA (Sederajat).

\section{Instrumen Penelitian}

Dalam penelitian ini, skala yang digunakan adalah skala perilaku konsumtif dan skala citra diri. Adapun skala perilaku konsumtif memiliki reliabilitas sebesar 0,718. Sementara pada skala citra diri memiliki reliabilitas sebesar 0,771 .

\section{Hasil}

Dari uji korelasi dapat diketahui pola hubungan antara variabel perilaku konsumtif dan citra diri.

Tabel 1.

Hasil Uji Hipotesis.

\begin{tabular}{ccc}
\hline $\begin{array}{c}\text { Hubungan } \\
\text { antar variabel }\end{array}$ & $\begin{array}{c}\text { Nilai } \\
\text { korelasi (r) }\end{array}$ & Sig.(p) \\
\hline $\begin{array}{c}\text { Hubungan } \\
\text { perilaku }\end{array}$ & & \\
$\begin{array}{c}\text { konsumtif } \\
\text { dengan citra } \\
\text { diri }\end{array}$ & 0,481 & $<0,05$ \\
\hline
\end{tabular}

Hasil dari uji korelasi terdapat bahwa nilai $r$ sebesar 0,481 $(p<0,05)$. Angka ini menunjukkan korelasi positif antara variabel perilaku konsumtif dan citra diri dengan nilai korelasi keeratan sedang. Sehingga dapat didapatkan hasil adanya hubungan yang signifikan antar kedua variabel.

\section{Diskusi}

Berdasarkan uji correlation bivariate Pearson, dihasilkan hubungan antara perilaku konsumtif pada produk $\mathrm{X}$ dengan citra diri remaja putri dengan $r$ hitung sebesar 0,481 yang berarti memiliki nilai korelasi keeratan sedang (Sugiyono, 2011). Jumlah subjek sebanyak 125 baik untuk perilaku konsumtif dan citra diri. Hipotesis dalam penelitian ini adalah terdapat hubungan positif antara perilaku konsumtif pada produk $\mathrm{X}$ dengan citra diri remaja putri.

Berdasarkan nilai sig. (2-tailed) sebesar 0,00 yang lebih kecil dari level of 
significant $(\alpha) \quad 5 \%$, maka $\mathrm{Ha}$ dapat diterima yang berarti hipotesis yang diajukan adalah teruji bahwa "ada hubungan positif antara perilaku konsumtif pada produk $\mathrm{X}$ dengan citra diri remaja putri”.

Data yang telah dianalisis menunjukkan bahwa terdapat hubungan antara perilaku konsumtif pada produk $\mathrm{X}$ dengan citra diri remaja putri. Hal ini tampak pada diperolehnya koefisien korelasi sebesar 0,481 dengan signifikansi 0,00 ini berarti terdapat hubungan antara perilaku konsumtif pada produk $\mathrm{X}$ dengan citra diri yang memiliki arah hubungan positif. Sehingga dapat dikatakan bahwa peningkatan citra diri akan diikuti dengan peningkatan perilaku konsumtif. Dengan demikian, semakin tinggi citra diri maka akan semakin tinggi perilaku konsumtif dan sebaliknya.

Hasil penelitian ini sejalan dengan yang diungkapkan oleh Aryani (2006) yang mengemukakan bahwa yang dapat mempengaruhi perilaku konsumtif di kalangan remaja adalah self-image yang selanjutnya disebut citra diri yang merupakan bagian dari konsep diri seseorang. Dalam memperoleh jati diri remaja berusaha membentuk citra atau image tentang dirinya dan upaya ini terlihat dalam suatu gambaran tentang bagaimana setiap remaja mempersepsikan dirinya. Termasuk di dalamnya bagaimana ia mencoba menampilkan diri secara fisik. Hal tersebut membuat mereka sensitif terhadap gambaran fisik sehingga mendorong mereka melakukan berbagai upaya agar tampilan fisiknya sesuai dengan tuntutan komunitas sosial mereka.

Sumarwan (dalam Utami, 2008) berpendapat bahwa gaya hidup menggambarkan perilaku seseorang, yaitu bagaimana seseorang itu hidup, menggunakan uang, dan memanfaatkan waktu yang dimiliki. Kaum remaja cenderung digiring menghabiskan uang sakunya untuk melampiaskan keinginannya. Rasa gengsi demi penampilan di hadapan semua temantemannya atau di kalangan masyarakat, membuat mereka terbiasa membohongi orang tuanya untuk meminta uang lebih dengan berbagai alasan, agar apapun yang diinginkan remaja tersebut tercapai. Kaum remaja itu sendiri sudah tidak lagi menghiraukan kondisi perekonomian orang tua mereka.

Remaja akhir terentang di usia 18-21 tahun (Mönk, dkk., 2006). Secara ekonomis, mereka masih harus tergantung selama beberapa tahun sampai pelatihan yang diperlukan untuk bekerja selesai dijalani (Hurlock, 1997). Masa remaja merupakan masa di mana rata-rata mereka masih menempuh pendidikan (sekolah) dan masih bergantung kepada orang tua. Remaja yang hampir menginjak usia dewasa (duduk di kelas terakhir bangku SMA) dianggap orang tua mampu memasuki dunia kerja maupun melanjutkan ke jenjang pendidikan yang lebih tinggi. Padahal, remaja yang masih melanjutkan ke jenjang pendidikan yang lebih tinggi sedang berproses untuk kemandirian ekonominya atau bias dikatakan secara finansial mereka masih bergantung kepada orang tua.

Dari penelitian yang telah dilakukan, maka peneliti akan mengajukan beberapa saran. Saran ini diharapkan akan berguna bagi penelitian selanjutnya mengenai perilaku konsumtif maupun citra diri.

\section{Saran Teoretis}

Diharapkan kepada peneliti berikutnya yang berminat meneliti tentang perilaku konsumtif dengan citra diri pada remaja 
putri dalam membeli produk $\mathrm{X}$ dengan mengkaji lebih mendalam dengan aspekaspek lainnya, agar mendapatkan hasil penelitian yang berbeda dengan penelitianpenelitian sebelumnya. Selain itu, sebaiknya peneliti selanjutnya mencoba mengikuti metode kualitatif dalam meneliti perilaku konsumtif dan citra diri ini, agar didapatkan hasil yang lebih luas dan mendalam.

\section{Saran Praktis}

Bagi remaja putri diharapkan dapat terus mengembangkan tugas-tugas perkembangannya sesuai dengan hal yang positif dan agar dapat memahami masalah tentang perilaku konsumtif yang terjadi di kalangan remaja putri dan harus dihindari sedini mungkin agar perilaku konsumtif tidak terus berkembang dan remaja putri itu sendiri dapat mengarahkan kepada halhal yang positif. Bagi peneliti selanjutnya diharapkan dapat menggali faktor-faktor lain yang mempengaruhi perilaku konsumtif, seperti sikap, perilaku, budaya, dan semacamnya, diharapkan dapat menggali lagi dalam penelitian selanjutnya yang dapat memberikan penjelasan bahwa perilaku konsumtif remaja putri memang benar-benar terbukti mempunyai citra diri yang tinggi.

\section{Kesimpulan}

Berdasarkan hasil dari analisis dan interprestasi data penelitian dapat disimpulkan bahwa berdasarkan nilai sig. (2-tailed) sebesar 0,00 yang lebih kecil dari level of significant ( $\alpha$ ) 5\%. Maka hipotesis yang diajukan peneliti yaitu bahwa "ada hubungan positif antara perilaku konsumtif pada produk $\mathrm{X}$ dengan citra diri remaja putri" diterima.

Data yang telah dianalisis menunjukkan bahwa terdapat hubungan antara perilaku konsumtif pada produk $\mathrm{X}$ dengan citra diri remaja putri. Hal ini menunjukkan bahwa dengan diperolehnya koefisien korelasi sebesar 0,481 dengan signifikansi 0,00 ini berarti terdapat hubungan antara perilaku konsumtif dengan citra diri yang memiliki arah hubungan positif. Hal ini berarti dapat dikatakan bahwa peningkatan perilaku konsumtif akan diikuti dengan peningkatan citra diri. Dengan demikian, semakin tinggi perilaku konsumtif maka akan semakin tinggi citra diri dan sebaliknya.

\section{Daftar Pustaka}

Aryani, G. (2006). Hubungan antara Konformitas dan Perilaku Konsumtif pada Remaja di SMA Negeri 1 Semarang. Skripsi. Semarang: Fakultas Ilmu Pendidikan Universitas Negeri Semarang

Hurlock, E. B. (1997). Psikologi Perkembangan: Suatu Pendekatan Sepanjang Rentang Kehidupan. Jakarta: Erlangga.

Mönks, F. J., Knoers, A. M. P., \& Haditono, S. R. (2006). Psikologi Perkembangan: Pengantar dalam Berbagai Bagiannya. Yogyakarta: Gadjah Mada University Press.

Rosandi, A. F. (2004). Perbedaan Perilaku Konsumtif antara Mahasiswa Pria dan Wanita di Universitas Katolik Atma Jaya. Jurnal. Yogyakarta: Fakultas Psikologi.

Sabirin, E. (2005). Kenapa Remaja Doyan Belanja. Semarang: PKBI Jateng.

Santrock, J. W. (2003). Adolescence: Perkembangan Remaja. Jakarta: Erlangga.

Sugiyono. (2011). Metode Penelitian Kuantitatif, Kuantitatif, dan $R \& D$. Bandung: Alfabeta.

Susianto. (1993). Studi Gaya Hidup sebagai Upaya Mengenali 
Kebutuhan Anak Muda. Jurnal Psikologi dan Masyarakat.

Utami, H. P. (2008). Perilaku Konsumtif pada Sales Promotion Girl (SPG) Ditinjau dari Gaya Hidup Hedonis. Skripsi. Semarang: Fakultas Psikologi Universitas Katolik Soegijapranata. 